\title{
1,2,4,5-Tetramethoxybenzene
}

\section{Suppresses House Dust Mite-Induced Allergic Inflammation in BALB/c Mice}

\author{
Meiling Jin ${ }^{\mathrm{a}}$ Jin Kyeong Choi ${ }^{\mathrm{a}}$ Young-Ae Choi ${ }^{\mathrm{a}}$ Yeon-Yong Kim ${ }^{\mathrm{a}}$ \\ Moon-Chang Baek ${ }^{b}$ Byung-Heon Lee ${ }^{c}$ Yong Hyun Jang ${ }^{d}$ Weon Ju Lee ${ }^{d}$ \\ Seok-Jong Lee ${ }^{d}$ Do Won Kim ${ }^{d}$ Hyun-Shik Lee ${ }^{e}$ Eui Kyun Park ${ }^{f}$ Soyoung Lee ${ }^{g}$ \\ Zee-Yong Park ${ }^{\text {h }}$ Sang-Hyun Kim ${ }^{\text {a }}$ \\ ${ }^{a}$ Department of Pharmacology, ${ }^{b}$ Department of Molecular Medicine, ${ }^{c}$ Department of Biochemistry and Cell Biology, \\ ${ }^{\mathrm{d}}$ Department of Dermatology, School of Medicine, ${ }^{e}$ School of Life Science and ${ }^{\mathrm{f}}$ Department of Oral Pathology, \\ School of Dentistry, Kyungpook National University, Daegu, ${ }^{9}$ Natural Product Research Center, Korea Research

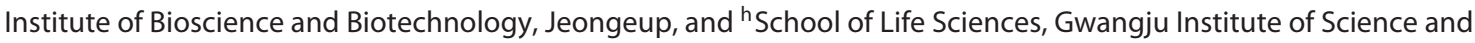 \\ Technology, Gwangju, Republic of Korea
}

\section{Key Words}

1,2,4,5-tetramethoxybenzene · DFE-induced allergic

inflammation $\cdot$ Keratinocytes

\begin{abstract}
Background: Atopic dermatitis (AD) is the most common allergic inflammatory skin disease. The activation of innate immunity by house dust mite (Dermatophagoides farinae extract, DFE) allergen plays an important role in the pathogenesis of AD. We previously showed the inhibitory effect of an extract of Amomum xanthioides on allergic diseases, and isolated 1,2,4,5-tetramethoxybenzene (TMB) as a major active component. In this study, we investigated whether TMB relieves DFE-induced allergic inflammation symptoms. Methods: We established a DFE-induced allergic inflammation model in BALB/c mice by repeated skin exposure to DFE. To define the underlying mechanisms of action, we used a tu-
\end{abstract}

M.J. and J.K.C. contributed equally to this work. (c) 2016 S. Karger AG, Basel

$1018-2438 / 16 / 1701-0035 \$ 39.50 / 0$ mor necrosis factor- $a$ and interferon- $\gamma$-activated human keratinocytes ( $\mathrm{HaCaT}$ cell line) and mouse keratinocytes (3PC cell line) cell line model. Results: Oral administration of TMB suppressed allergic inflammation symptoms, such as histopathological analysis and ear thickness, in addition to serum IgE, DFE-specific lgE and IgG2a levels. TMB decreased the serum histamine levels and tissue infiltration of inflammatory cells, including mast cells and eosinophils. TMB also inhibited $\mathrm{CD} 4^{+} \mathrm{IFN}-\gamma^{+}, \mathrm{CD}^{+} \mathrm{IL}-4^{+}$, and $\mathrm{CD} 4^{+} \mathrm{IL}-17 \mathrm{~A}^{+}$lymphocyte expansion in the draining lymph nodes and expression of the Th2 cytokines in the ear tissue. TMB significantly inhibited the expression of cytokines and chemokines by the downregulation of the mitogen-activated protein kinases and nuclear factor of activated cytoplasmic T cells in $\mathrm{HaCaT}$ cells. Conclusions: TMB improved DFE-induced allergic inflammation by suppressing the production of proinflammatory cytokines and chemokines. Our results suggest that TMB might be a potential therapeutic agent for AD.

\section{KARGER}

E-Mail karger@karger.com

www.karger.com/iaa
Correspondence to: Dr. Sang-Hyun Kim

Department of Pharmacology, School of Medicine, Kyungpook National University 2-101 Dongin-dong, Jung-gu

Daegu 700-422 (Republic of Korea)

E-Mail shkim72@ knu.ac.kr

Dr. Zee-Yong Park

School of Life Sciences, Gwangju Institute of Science and Technology

Cheomdan Gwagiro 123, Buk-gu

Gwangju 61005 (Republic of Korea)

E-Mail zeeyong@gist.ac.kr 


\section{Introduction}

Atopic dermatitis (AD) is a complex and chronic inflammatory skin disease caused by multiple factors, including susceptibility genes, and immunologic and environmental factors [1]. Among the environmental factors, Dermatophagoides farinae is important for the pathogenesis of $\mathrm{AD}$ through the induction of both acute and chronic $\mathrm{AD}$ lesions [2]. Currently, $\mathrm{AD}$ is considered a biphasic T cell-mediated disease; Th2 cells predominate the acute phase and the switch to Th1 promotes the chronic phase [3]. Th1/Th2 imbalance is one of the major factors for $\mathrm{AD}$, and Th17 also contributes to its pathogenesis $[4,5]$. Th17 cells coordinate local tissue inflammation through the upregulation of proinflammatory cytokines and chemokines [6]. High levels of Th2 cytokines such as interleukin (IL)-4 and IL-13 in AD skin lesions induce immunoglobulin class switching, promoting excessive IgE production [7]. In addition, Th1 cells producing IFN- $\gamma$ are predominant in the chronic phase of $\mathrm{AD}$, and Th17 cells are increased in the acute phase of $\mathrm{AD}[8,9]$. The activation of keratinocytes is a hallmark of the pathogenesis of AD [2]. Keratinocytes have an effect on immune responses during the development of $\mathrm{AD}$ [10]. In patients with $\mathrm{AD}$, keratinocytes promote inflammation by the secretion of various cytokines and chemokines [11].

Although AD is one of the most common inflammatory skin diseases, therapeutic options for $\mathrm{AD}$ patients with moderate-to-severe cases of the disease are limited [5]. Corticosteroids and immunosuppressant drugs are effective treatments for $\mathrm{AD}$. Cyclosporine $\mathrm{A}$ (CsA) is a highly effective treatment for $\mathrm{AD}$, which interferes with calcineurin and the nuclear factor of activated $\mathrm{T}$ cells (NFAT) [12]. However, the long-term use of corticosteroids and immunosuppressant drugs is associated with a number of potentially serious adverse effects. Recently, several natural extracts have been introduced for the potential treatment of AD. Several studies have demonstrated that the extract of Amomum xanthioides has antiallergic, antioxidative and anti-inflammatory effects $[13,14]$. In addition, the natural extract $\beta$-sitosterol from $A$. xanthioides showed inhibitory effects on $\mathrm{AD}$ [15]. We previously showed that 1,2,4,5-tetramethoxybenzene (TMB), extracted from A. xanthioides, has antiallergic inflammatory effects [16]. Based on the known antiallergic and anti-inflammatory effects of TMB, we investigated the effects of TMB using DFE-induced allergic inflammation models.

\section{Materials and Methods}

\section{Animals}

Six-week-old female BALB/c mice were purchased from SLC Inc. (Hamamatsu, Japan). The animals were housed with 5-10 mice per cage in a laminar airflow room maintained at a temperature of $22 \pm 2{ }^{\circ} \mathrm{C}$ with a relative humidity of $55 \pm 5 \%$ throughout the study. The care and treatment of the mice were carried out in accordance with the guidelines established by the Public Health Service Policy on the Humane Care and Use of Laboratory Animals and were approved by the Institutional Animal Care and Use Committee.

\section{Reagents}

D. farinae extract (DFE, Greer Laboratories, Lenoir, N.C., USA) was used as an antigen. All reagents were procured from Sigma (St. Louis, Mo., USA) unless otherwise stated. DFE was dissolved in phosphate-buffered saline (PBS) containing $0.5 \%$ Tween 20. Recombinant human tumor necrosis factors (TNF)- $\alpha$ and interferon (IFN) $-\gamma$ were purchased from R\&D systems (Minneapolis, Minn., USA).

\section{Extraction of A. xanthioides and Isolation of TMB}

Fruits of A. xanthioides were purchased from Yak-Ryung-Si Market in Daegu, Korea, and identified by Dr. Seung Ho Lee at the College of Pharmacy, Yeungnam University, Korea, where a voucher specimen (YU00194) was deposited in the Natural Product Laboratory. Dried fruits of $A$. xanthioides $(9.5 \mathrm{~kg}$ ) were extracted with methanol $(\mathrm{MeOH} ; 15$ liters $\times 3)$ at room temperature. The extracts were concentrated in vacuo to produce a black gum (440 g), which was dissolved in $\mathrm{H}_{2} \mathrm{O}$, continuously partitioned with solvents, and then respectively concentrated to give extracts of $n$-hexane ( $120 \mathrm{~g})$, methylene chloride (MC; $32.7 \mathrm{~g}$ ), ethyl acetate (9.8 g) and $\mathrm{H}_{2} \mathrm{O}(275.1 \mathrm{~g})$. The MC-soluble extract (32.7 g) eluted with a gradient mixture of $100 \% \mathrm{MC}$ to $100 \%$ acetone was chromatographed on a silica gel liquid chromatography to obtain seven fractions (AF1-AF7). TMB was isolated from fraction AF3 (101.2 $\mathrm{mg})$ using preparative HPLC $\left(\mathrm{C}_{18}, 250 \times 21.2 \mathrm{~mm}\right.$, flow rate $6 \mathrm{ml} /$ min) and eluted with $\mathrm{MeOH}: \mathrm{H}_{2} \mathrm{O}$ (gradient from 30:70 to 60:40). Column chromatography was carried out on Merck silica gel (70230 mesh) and Merck Lichroprep RP-18 gel (40-63 $\mu \mathrm{m})$. HPLC separation was performed with the Gilson system, a UV detector, and a Luna $\mathrm{C}_{18}$ column $(250 \times 21.20 \mathrm{~mm}, 10 \mu \mathrm{m})$. Thin-layer chromatography was performed using aluminum plates precoated with silica gel $60 \mathrm{~F}_{254}$ and RP-18 $\mathrm{F}_{254}$ (Merck, Darmstadt, Germany). Compounds were detected under UV light and then visualized by spraying the plates with vanillin-sulfuric acid reagent ( $1 \%$ ethanolic vanillin solution, $10 \%$ ethanolic sulfuric acid) and $10 \%$ sulfuric acid followed by heating at $110^{\circ} \mathrm{C}$ for $1 \mathrm{~min} .{ }^{1} \mathrm{H}(250 \mathrm{MHz})$ and ${ }^{13} \mathrm{C}(63 \mathrm{MHz}) \mathrm{NMR}$ spectra were recorded on a Bruker $250 \mathrm{MHz}$ (DMX 250) with tetramethylsilane as an internal standard. NMR spectra were recorded on JEOL ECA-500 $\left({ }^{1} \mathrm{H}, 500 \mathrm{MHz},{ }^{13} \mathrm{C}, 125\right.$ $\mathrm{MHz}$ ) spectrometers. All NMR experiments were performed at $294 \mathrm{~K}$. TMB was dissolved in dimethyl sulfoxide (DMSO) and then diluted with PBS. The proportion of DMSO in the treated samples was controlled to less than $0.1 \%$ to minimize the interference.

\section{Cell Culture and Viability}

A human keratinocytes cell line ( $\mathrm{HaCaT})$ was incubated in Dulbecco's modified Eagle's medium (Invitrogen, Grand Island, N.Y., USA), supplemented with $10 \%$ fetal bovine serum (FBS) and
Jin/Choi/Choi/Kim/Baek/Lee/Jang/Lee/ Lee/Kim/Lee/Park/Lee/Park/Kim 
antibiotics ( $100 \mathrm{U} / \mathrm{ml}$ penicillin $\mathrm{G}, 100 \mu \mathrm{g} / \mathrm{ml}$ streptomycin), in a $5 \% \mathrm{CO}_{2}$ incubator at $37^{\circ} \mathrm{C}$. A murine keratinocyte cell line (3PC) was cultured in Eagle's minimal essential medium (Lonza, Basel, Switzerland), supplemented with insulin $(2.5 \mu \mathrm{g} / \mathrm{ml})$, epidermal growth factor $(5 \mathrm{ng} / \mathrm{ml})$, transferrin $(10 \mu \mathrm{g} / \mathrm{ml}), o$-phosphoethanolamine $(10 \mu \mathrm{M})$, ethanolamine $(10 \mu \mathrm{M})$, penicillin $(50 \mathrm{U} / \mathrm{ml})$, hydrocortisone $(0.5 \mu \mathrm{g} / \mathrm{ml}), \mathrm{CaCl}_{2}(0.03 \mathrm{mM})$ and $1 \%$ fetal bovine serum. Cell viability was determined using the 3 -(4,5-dimethylthiazolyl-2)2,5-diphenyl-tetrazolium bromide assay (MTT). HaCaT cells were treated with TMB for $24 \mathrm{~h}$ and MTT $(5 \mathrm{mg} / \mathrm{ml})$ was added into each well that contained a sample and incubated at $37^{\circ} \mathrm{C}$ for an additional $2 \mathrm{~h}$. Isopropanol was added to dissolve the formazan crystals. The absorbance on each sample compared to that of the control was calculated and expressed as a percentage.

\section{Induction of DFE-Induced Allergic Inflammation in the}

Mouse Ear

The induction of DFE-induced allergic inflammation was performed based on our previous research $[17,18]$. A schematic experimental procedure is described in online supplementary fig. S2a (see www.karger.com/doi/10.1159/000446510 for all online suppl. material). Mice (total $n=35)$ were allocated to seven groups $(n=$ 5 per group): vehicle, TMB (25 mg/kg), DFE plus vehicle, DFE plus TMB $(1,5$ or $25 \mathrm{mg} / \mathrm{kg})$, or CsA (30 mg/kg). The surfaces of both ear lobes were gently stripped five times with surgical tape (Nichiban, Tokyo, Japan). After stripping, $20 \mu \mathrm{l}$ of DFE $(10 \mathrm{mg} / \mathrm{ml})$ was painted on each ear. The treatment with DFE was repeated twice weekly for 6 weeks. The ear thickness was measured $24 \mathrm{~h}$ after DFE application with a dial thickness gauge (Mitutoyo Co., Tokyo, Japan). Two weeks after the first induction, tail bleeding was performed to check the serum IgE level. After confirming an atopic condition by IgE level, TMB (1, 5 or $25 \mathrm{mg} / \mathrm{kg})$ or CsA $(30 \mathrm{mg} / \mathrm{kg})$ was orally administered five times per week, until the end of the 6 -week induction period (in total 20 times).

On day 42, the animals were euthanized with carbon dioxide. Blood samples were collected from the celiac artery. For serum, the blood was allowed to clot by leaving it undisturbed at room temperature, the clot was removed and centrifuged at 2,000 $\mathrm{g}(15 \mathrm{~min}$, $4^{\circ} \mathrm{C}$ ) and the supernatant was retained. After blood collection, ears were removed and used for histopathological analysis and RNA extraction. Total serum IgE and IgG2a were measured using an ELISA kit (BD Biosciences, Oxford, UK) according to the manufacturer's instructions. For the detection of DFE-specific IgE, 96-well plates (Nunc, Wiesbaden, Germany) were coated with $10 \mathrm{mg}$ of mite extract. The DFE-specific IgE level was indicated by the OD value.

\section{Histological Observation}

The ears (total $n=35$ ) were fixed with $10 \%$ formaldehyde and embedded in paraffin. Five-micrometer sections were stained with hematoxylin and eosin (H\&E). Infiltrated lymphocytes, thickening of the epidermis and fibrosis in the dermis were observed using a microscope, as described in previous research [19]. For the measurement of mast cell infiltration, skin sections were stained with toluidine blue and the number of mast cells at five randomly selected fields was measured for each sample at a magnification of $\times 200$. Eosinophils in H\&E-stained sections were counted in 10 high-power fields at a magnification of $\times 400$. Dermal thickness was analyzed in $\mathrm{H} \& \mathrm{E}$-stained sections viewed under a magnification of $\times 200$. The thickness was measured in five randomly selected fields from each sample.

TMB Relieves Mite-Induced Allergic Inflammation

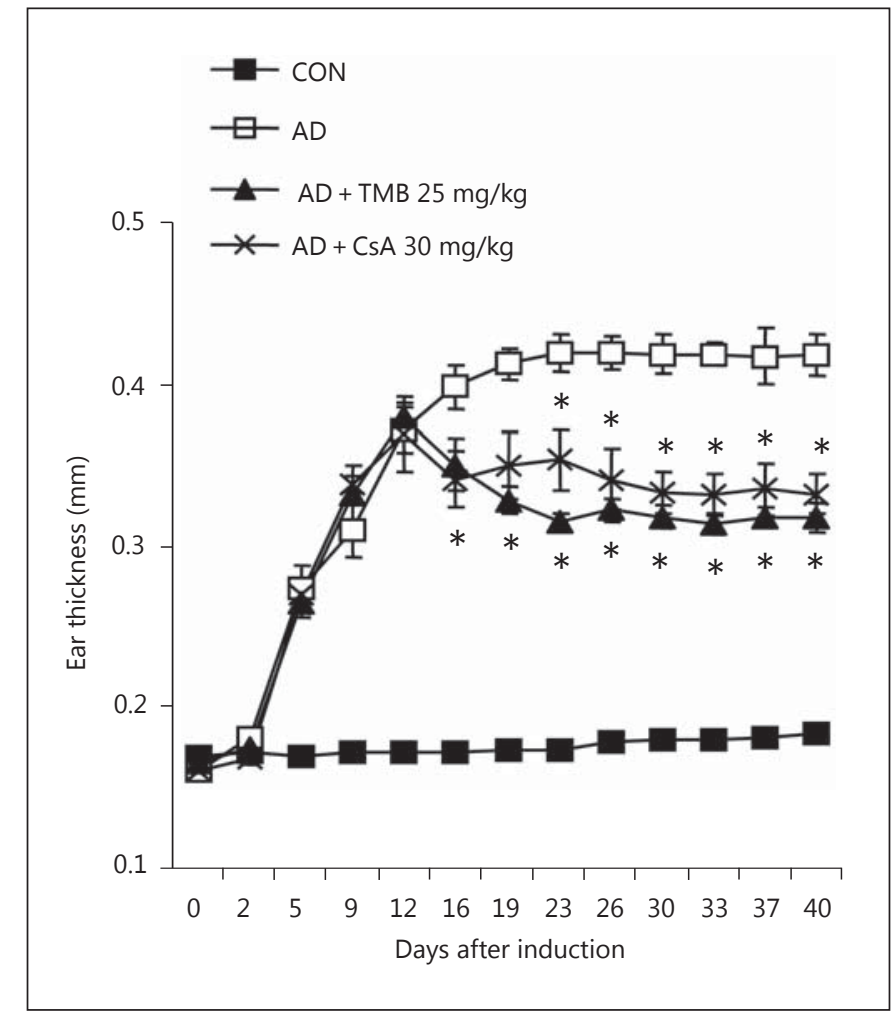

Fig. 1. Development of DFE-induced allergic inflammation. TMB $(1,5$ or $25 \mathrm{mg} / \mathrm{kg})$ or CsA (30 mg/kg) was orally administered five times per week, beginning on day 16 after the first induction. Ear thickness was measured $24 \mathrm{~h}$ after DFE application with a dial thickness gauge. Five mice were placed into each of seven groups: vehicle, TMB (25 mg/kg), DFE plus vehicle, DFE plus TMB $(1,5$, or $25 \mathrm{mg} / \mathrm{kg})$, or CsA (30 mg/kg). AD = DFE-induced allergic inflammation. Data are presented as the mean \pm SE $(n=5) .{ }^{*} \mathrm{p}<$ 0.05 , significantly lower than $\mathrm{AD}$.

\section{Histamine Assay}

The histamine content was measured using the $o$-phthaldialdehyde spectrofluorometric procedure based on a previous study [20]. Blood from the mice (total $\mathrm{n}=35$ ) was centrifuged at $400 \mathrm{~g}$ for $10 \mathrm{~min}$, and serum was withdrawn to measure the histamine content. The fluorescent intensity was measured using 355-nm excitation and 450-nm filters and the LS-50B fluorescence spectrometer (Perkin-Elmer, Norwalk, Conn., USA).

\section{FACS}

At the end of the experiment, the mice (total $n=35$ ) were euthanized and both auricular lymph nodes were collected from each mouse. The auricular lymph nodes $(\mathrm{n}=70)$ were ground using 70 $\mu \mathrm{m}$ nylon cell strainers (Falcon, Bedford, Mass., USA) to isolate single cells. The cells were stained using a mouse CD4 PerCPCy ${ }^{\mathrm{TM}}$ 5.5-FITC-conjugated Th1 (IFN- $\gamma$ ), CD4 PerCP-Cy ${ }^{\mathrm{TM}} 5.5-$ APC-conjugated Th2 (IL-4) and CD4 PerCP-Cy ${ }^{\mathrm{TM}}$ 5.5-PE-conjugated Th17 (IL-17A) phenotyping kit (BD Biosciences) according to the manufacturer's instructions. The fluorescence intensity was detected using a FACSCalibur flow cytometer (BD Biosciences).

Int Arch Allergy Immunol 2016;170:35-45 


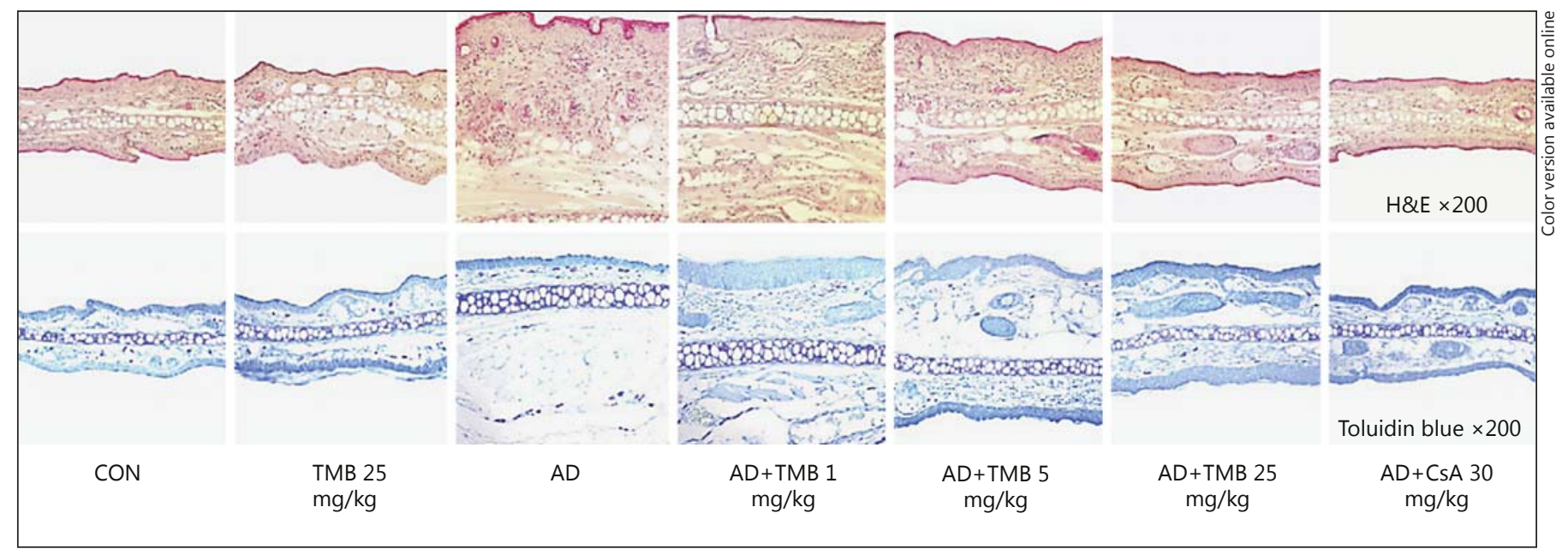

Fig. 2. Histological analysis and cell infiltration in DFE-induced allergic inflammation. Representative photomicrographs of ear sections were stained with H\&E (original magnification $\times 200$ ) or toluidine blue (original magnification $\times 200$ ). Five mice were placed into each of the seven groups indicated. $A D=D F E-i n d u c e d$ allergic inflammation.

\section{Quantitative Real-Time Polymerase Chain Reaction}

To detect the expression of cytokines, a quantitative real-time PCR was performed using a Thermal Cycler Dice TP850 (Takarabio Inc., Shiga, Japan) according to the manufacturer's protocol. At the end of the in vivo experimental period, the ears were excised and total RNA was isolated. $\mathrm{HaCaT}$ cells and $3 \mathrm{PC}$ cells were pretreated with TMB for $1 \mathrm{~h}$, followed by stimulation with TNF- $\alpha(10$ $\mathrm{ng} / \mathrm{ml})$ and IFN- $\gamma(10 \mathrm{ng} / \mathrm{ml})$ for 6 and $24 \mathrm{~h}$, respectively. Total cellular RNA was isolated from cells $\left(2 \times 10^{5}\right.$ cells/24-well plate), using RNAiso Plus (Takarabio Inc.). The first strand of complementary DNA (cDNA) was synthesized using RT Premix (iNtRON Biotech, Sungnam, Korea). The reverse transcription conditions were at $45^{\circ} \mathrm{C}$ for $60 \mathrm{~min}$ and at $95^{\circ} \mathrm{C}$ for $5 \mathrm{~min}$. Briefly, $2 \mu \mathrm{l}$ of cDNA (100 ng), $1 \mu \mathrm{l}$ of sense and antisense primer solution (0.4 $\mu \mathrm{M}), 12.5 \mu \mathrm{l}$ of SYBR Premix Ex Taq (Takara Bio Inc.) and $8.5 \mu \mathrm{l}$ of $\mathrm{dH}_{2} \mathrm{O}$ were mixed together to obtain a reaction mixture with a final volume of $25 \mu \mathrm{l}$ in each reaction tube. The conditions for the PCR were similar to our previous report [17] except for the primers of mouse $\beta$-actin ( $\mathrm{F} 5^{\prime}$-TAG ACT TCG AGC AGG AGA TG-3', R 5'-TTG ATC TTC ATG GTG CTA GG-3'), mouse TNF- $\alpha$ (F $5^{\prime}$-GGC AGG TCT ACT TTG GAG TCA TTG C-3', R 5'-ACA TTC GAG GCT CCA GTG AAT TCG AAT TCG G-3'), mouse IL-1 $\beta$ (F 5'-ATA ACC TGC TGG TGT GTG AC-3', R 5'-AGG TGC TGA TGT ACC AGT TG-3'), mouse IL-13 (F $5^{\prime}$-GCA ACA TCA ACA GGA CCA GA-3', R 5'-GTC AGG GAA TCC AGG GCT AC- $3^{\prime}$ ), human TNF- $\alpha$ (F $5^{\prime}$-CCC TCC AGT TCT AGT TCT ATC-3', R 5'-GGG GAA AGA ATC ATT CAA CCA G-3'), human IL- $1 \beta$ (F $5^{\prime}$-ACG ATG CAC CTG TAC GAT CA- $3^{\prime}$, R $5^{\prime}$-TCT TTC AAC ACG CAG GAC AG- $3^{\prime}$ ), human IL-6 (F $5^{\prime}$-TTC CCT CAG GAT GGT GTC TC-3' ${ }^{\prime}$ R $5^{\prime}$-AAA TGC CCA ACA GAG GTC AC$3^{\prime}$ ), human TARC/CCL17 (F 5'-ACT GCT CCA GGG ATG CCA TCG TTT-3', R 5'-ACA AGG GGA TGG GAT CTC CCT CAC-3') and human MDC/CCL22 (F $5^{\prime}$-AGG ACA GAG CAT GGC TCG CCT ACA GA-3', R 5'-TAA TGG CAG GGA GGT AGG GCT
CCT GA-3'). The normalization and quantification of mRNA expression were performed using TP850 software supplied by the manufacturer. The expression levels of $\beta$-actin were used for normalization.

\section{Nuclear Protein Extraction}

Nuclear protein extraction procedures were based on our previous study [19]. HaCaT cells $\left(1 \times 10^{6}\right.$ cells/ 6 -well plate $)$ were pretreated with TMB for $1 \mathrm{~h}$, followed by stimulation with TNF-a (10 $\mathrm{ng} / \mathrm{ml})$ and IFN- $\gamma(10 \mathrm{ng} / \mathrm{ml})$ for $30 \mathrm{~min}$. After stimulation, cells were washed in $1 \mathrm{ml}$ of ice-cold PBS, centrifuged at $1,200 \mathrm{~g}$ for $5 \mathrm{~min}$, resuspended in $400 \mu \mathrm{l}$ of ice-cold hypotonic buffer $(10 \mathrm{mM}$ HEPES/KOH, $2 \mathrm{mM} \mathrm{MgCl}_{2}$, $0.1 \mathrm{mM}$ EDTA, $10 \mathrm{mM} \mathrm{KCl,} 1 \mathrm{mM}$ DTT, $0.5 \mathrm{mM}$ PMSF, pH 7.9), left on ice for $10 \mathrm{~min}$, vortexed and centrifuged at $15,000 \mathrm{~g}$ for $30 \mathrm{~s}$. After washing, the pelleted nuclei were resuspended in $50 \mu \mathrm{l}$ of ice-cold saline buffer ( $50 \mathrm{mM}$ HEPES/ $\mathrm{KOH}, 50 \mathrm{mM} \mathrm{KCl}, 300 \mathrm{~mm} \mathrm{NaCl}, 0.1 \mathrm{~mm}$ EDTA, 10\% glycerol, $1 \mathrm{mM}$ DTT, 0.5 mM PMSF, pH 7.9), left on ice for $20 \mathrm{~min}$, vortexed, centrifuged at $15,000 \mathrm{~g}$ for $5 \mathrm{~min}$ at $4^{\circ} \mathrm{C}$, and then the supernatant was gathered.

\section{Western Blot}

Samples for the Western blot were prepared as described in previous research [21]. Briefly, cells $\left(1 \times 10^{6}\right.$ cells/6-well plate $)$ were stimulated for $30 \mathrm{~min}$ for MAPKs and NFAT. Cells were then rinsed twice with ice-cold PBS and the total cell lysates were gathered in $200 \mu \mathrm{l}$ of lysis buffer. The lysates were spun in a microcentrifuge for $20 \mathrm{~min}$ at $4^{\circ} \mathrm{C}$ and the supernatant was collected. Proteins were electrophoresed using 8-12\% SDS-PAGE and transferred to nitrocellulose membranes. The membranes were stained with reversible Ponceau $S$ to ensure equal loading of the samples in the gel. The nucleus NFATc1 was assayed using anti-NFATc1 antibodies (Santa Cruz Biotech., Santa Cruz, Calif., USA). The phosphorylation of ERK, JNK and STAT1 was determined using 


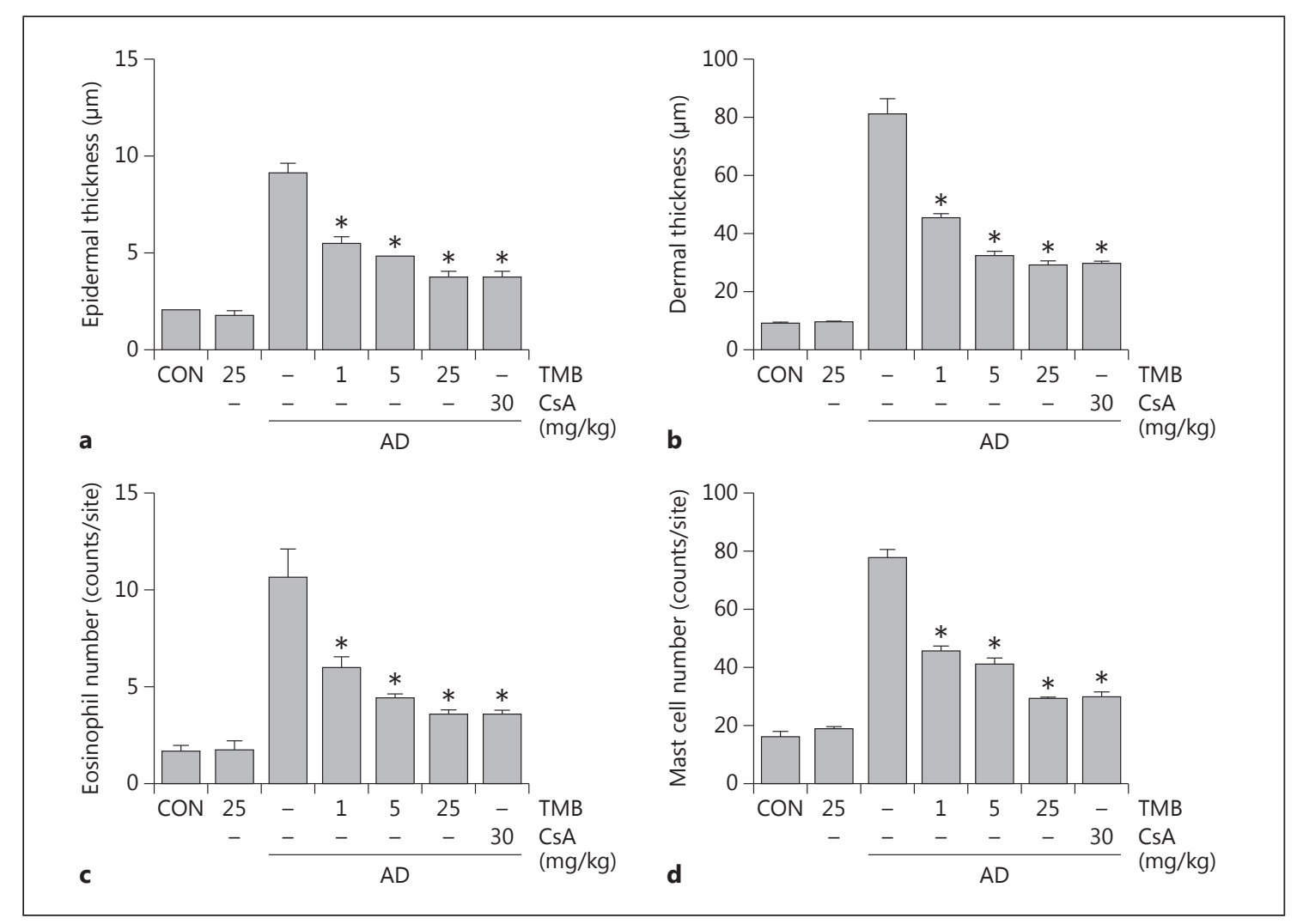

Fig. 3. Histological analysis and cell infiltration in DFE-induced allergic inflammation. a, b Epidermal and dermal thickness were analyzed in H\&E-stained sections, viewed at a magnification of $\times 200$. c Eosinophils in H\&Estained sections were counted in 10 high-power fields at a magnification of $\times 400$. $\mathbf{d}$ Mast cells in toluidine bluestained sections were counted in five fields at $\times 200$. Five mice were placed into each of seven groups: vehicle, TMB (25 mg/kg), DFE plus vehicle, DFE plus TMB (1, 5 or $25 \mathrm{mg} / \mathrm{kg})$, or CsA (30 mg/kg). AD = DFE-induced allergic inflammation. Data are presented as the mean $\pm S E(n=5) . * p<0.05$, significantly lower than AD.

anti-phospho-ERK, anti-phospho-JNK and anti-phospho-STAT1 antibodies (Cell Signaling, Beverly, Mass., USA). Immunodetection was performed using the SuperSignal West Pico Chemiluminescent Substrate (Thermo Scientific, Waltham, Mass., USA).

\section{Statistical Analysis}

Statistical analyses were performed using Prism 5 (GraphPad Software, San Diego, Calif., USA). Treatment effects were analyzed using one-way analysis of variance followed by Dunnett's test. A value of $\mathrm{p}<0.05$ was used to indicate statistically significant differences.

\section{Results}

\section{Effects of TMB on DFE-Induced Allergic}

Inflammation in Mice

To determine the effect of TMB on $\mathrm{AD}$, we used a DFE-induced allergic inflammation mouse model. Dur- ing the induction period, ear swelling was measured $24 \mathrm{~h}$ after each induction. There was no difference in the ear swelling between the groups until 2 weeks. After 3 weeks of induction the oral administration of TMB $(1,5$ or 25 $\mathrm{mg} / \mathrm{kg}$ ) showed significant improvements in ear thickness (fig. 1; online suppl. fig. S1). TMB and CsA, a positive control, did not alter the body weight of the animals (online suppl. fig. S2b).

Histological analysis showed alterations, such as epidermal and dermal thickness, hyperkeratosis and infiltration of eosinophils in DFE-induced allergic inflammation. The oral administration of TMB $(1,5$, or $25 \mathrm{mg} / \mathrm{kg})$ markedly diminished the thickness of epidermal and dermal layers and eosinophil infiltration compared with DFE-induced allergic inflammation (fig. 2, fig. 3a-c; online suppl. fig. S3a). Photographs of the mice applied with DFE and each drug are shown in online supplementary 


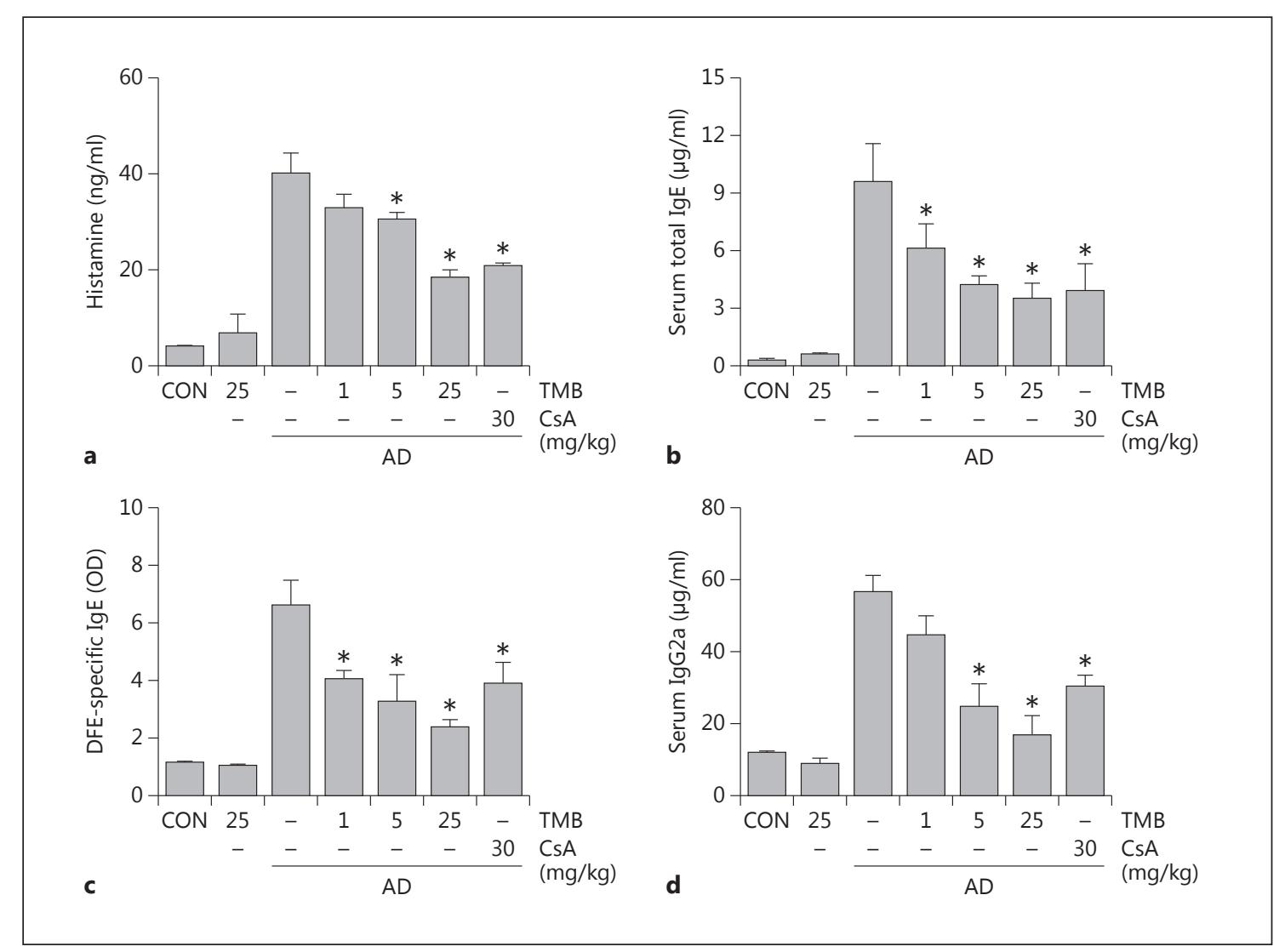

Fig. 4. Serum levels of immunoglobulin and histamine in DFE-induced allergic inflammation. a Histamine levels were detected using a fluorescent plate reader. Serum total IgE levels (b), DFE-pecific IgE levels (c) and serum total IgG2a levels (d) were measured by ELISA. Samples of the vehicle, TMB (25 mg/kg), DFE plus vehicle, DFE plus TMB (1, 5 or $25 \mathrm{mg} / \mathrm{kg}$ ), or CsA (30 mg/kg) groups were collected by orbital puncture on day 42 . AD = DFE-induced allergic inflammation. Data are presented as the mean $\pm \mathrm{SE}(\mathrm{n}=5) .{ }^{*} \mathrm{p}<0.05$, significantly lower than AD.

figure S3b. Mast cells are tissue immune cells that originate from hematopoietic cells and are a major source of histamine and proinflammatory cytokines [22, 23]. Skin sections were stained with toluidine blue for the measurement of mast cell infiltration. We examined the infiltration of mast cells in the ear tissue and the serum levels of histamine. TMB decreased both the infiltration of mast cells and serum histamine (fig. 3d, 4a). The efficacy of TMB was similar to the CsA.

\section{Effects of TMB on the Serum Immunoglobulin and Expression of Cytokines}

$\mathrm{AD}$ is associated with the Th2 phenotype, elevated IL-4 and IL-13 secretion, and increased serum IgE levels [24]. IL-4 mediates IgE isotype switching, and IFN- $\gamma$ mediates IgG2a isotype switching [8]. To investigate the role of TMB on the Th1 or Th2 response, we examined the serum levels of total IgE, DFE-specific IgE and IgG2a. Oral administration of TMB reduced total serum IgE, DFE-specific IgE and IgG2a levels compared to the DFEinduced allergic inflammation group (fig. $4 b-d$ ).

$\mathrm{AD}$ is characterized by a biphasic, $\mathrm{T}$ cell polarization, dominated by the infiltration of Th2 cells and cytokines such as IL-4, IL-5 and IL-13 in the acute phase and switch to a Th1 phenotype in chronic AD lesions [9]. In addition, Th17 cells have been described as essential factors in the pathophysiology of AD [9]. We investigated whether TMB regulates the Th1, Th2 and Th17 immune responses by measuring $\mathrm{T}$ cell populations and the expression of inflammatory cytokines in DFE-induced allergic inflammation. $\mathrm{CD} 4^{+} \mathrm{T}$ cells were isolated from the auricular lymph nodes and analyzed by FACS analysis. The $\mathrm{CD} 4^{+} \mathrm{IFN}-\gamma^{+}$, $\mathrm{CD}^{+} \mathrm{IL}^{-} 4^{+}$and $\mathrm{CD} 4^{+} \mathrm{IL}-17 \mathrm{~A}^{+}$populations were significantly decreased by TMB compared to the DFE-induced
40

Int Arch Allergy Immunol 2016;170:35-45 DOI: $10.1159 / 000446510$
Jin/Choi/Choi/Kim/Baek/Lee/Jang/Lee/ Lee/Kim/Lee/Park/Lee/Park/Kim 
allergic inflammation group (fig. 5; online suppl. fig. S4). The mRNA expression of Th1 (TNF- $\alpha$ and IFN- $\gamma$ ), Th2 (IL-4, IL-13 and IL-31) and Th17 (IL-17A) was markedly increased in DFE-induced allergic inflammation; TMB suppressed the expression of TNF- $\alpha$, IFN- $\gamma$, IL-4, IL-13, IL-31 and IL-17A in a dose-dependent manner (fig. 6).

\section{Effects of TMB on the Activation of Keratinocytes}

A keratinocyte model was used to clarify the biological functions and molecular mechanisms of TMB. We first tested the cytotoxicity of TMB in human keratinocyte cell lines (HaCaT). TMB did not show cytotoxicity up to 10 $\mu \mathrm{M}$ (online suppl. fig. S5). CsA, an immunosuppressant for severe $\mathrm{AD}$, was used as a positive control. Keratinocytes promote chronic, self-amplifying loops of immune activation by producing inflammatory factors [25]. Therefore, human keratinocytes produce thymus and activation-regulated chemokines (TARC/CCL17) and macrophage-derived chemokines (MDC/CCL22) in response to TNF- $\alpha / \mathrm{IFN}-\gamma$, which are thought to play an important role in the pathogenesis of $\mathrm{AD}[2,26]$. To investigate the inhibitory effects of TMB on the TNF- $\alpha / \mathrm{IFN}-\gamma$-induced expression of cytokines and chemokines in $\mathrm{HaCaT}$ cells, the cells were pretreated with TMB for $1 \mathrm{~h}$ and then stimulated with TNF- $\alpha /$ IFN- $\gamma$ for $6 \mathrm{~h}$. Quantitative real-time PCR showed that TMB suppressed the TNF- $\alpha /$ IFN- $\gamma$ induced gene expression of TNF- $\alpha$, IL-1 $\beta$, IL- 6 , TARC/ CCL17 and MDC/CCL22 in a dose-dependent manner (fig. 7a). In addition, the inhibitory effects of TMB on the TNF- $\alpha$ /IFN- $\gamma$-induced expression of cytokines were confirmed using mouse keratinocytes (3PC cells) (fig. 7b).

Previous studies showed that intracellular MAPK signaling pathways were activated by TNF- $\alpha / \mathrm{IFN}-\gamma$ in $\mathrm{HaCaT}$ cells [27]. The JAK/STAT signaling pathways contribute to the production of chemokines (TARC/ CCL17 and MDC/CCL22) in TNF- $\alpha /$ IFN- $\gamma$-induced $\mathrm{HaCaT}$ cells [28]. In addition, the NFAT family of transcription factors plays an important role in the immune system by the regulation of proinflammatory cytokines [29]. To investigate the mechanism responsible for the inhibitory effect of TMB on cytokine expression, we examined the effect of TMB on the TNF- $\alpha / \mathrm{IFN}-\gamma$-induced activation of MAPKs, STAT1 and NFATc1. HaCaT cells were pretreated with TMB for $1 \mathrm{~h}$ and then stimulated with TNF- $\alpha / \mathrm{IFN}-\gamma$ for $30 \mathrm{~min}$. TMB reduced the TNF- $\alpha /$ IFN- $\gamma$-induced phosphorylation of ERK and NFATc1, but did not alter the activation of JNK and STAT1 (fig. 8). These results suggest that TMB inhibits TNF- $\alpha / \mathrm{IFN}-\gamma$ induced expression of cytokines and chemokines by reducing activation of ERK and NFATc1 in keratinocytes.

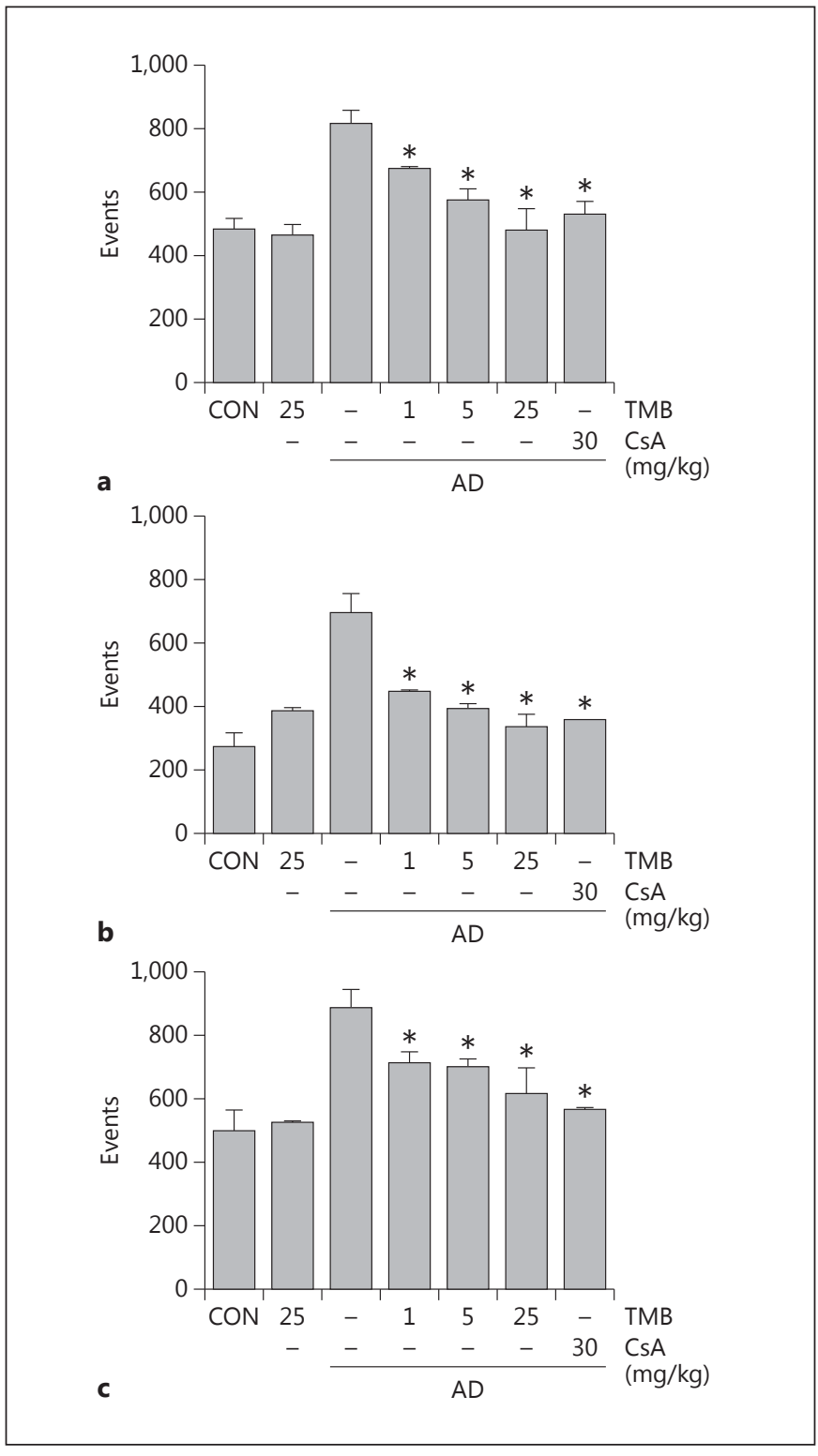

Fig. 5. Phenotypes of $\mathrm{T}$ lymphocytes in the draining lymph node of DFE-induced allergic inflammation. Both auricular lymph nodes were collected from each mouse. From the isolated single cells, the numbers of $\mathrm{CD} 4^{+} \mathrm{IFN}-\gamma^{+}(\mathbf{a}), \mathrm{CD} 4^{+} \mathrm{IL}-4^{+}(\mathbf{b})$ and $\mathrm{CD}^{+} \mathrm{IL}-17 \mathrm{~A}^{+}$(c) were detected by FACSCalibur. Five mice were placed into each of the seven groups: vehicle, TMB $(25 \mathrm{mg} / \mathrm{kg})$, DFE plus vehicle, DFE plus TMB (1, 5 or $25 \mathrm{mg} / \mathrm{kg})$, or CsA (30 $\mathrm{mg} / \mathrm{kg}) . \mathrm{AD}=\mathrm{DFE}$-induced allergic inflammation. Data are presented as the mean \pm SE $(n=10)$. ${ }^{*} \mathrm{p}<0.05$, significantly lower than $\mathrm{AD}$. 
Fig. 6. Expression of cytokines in the ears of mice with DFE-induced allergic inflammation. Ears were excised and total RNA was isolated. The quantitative real-time PCR was performed as described in Materials and Methods. Five mice were placed into each of the seven groups indicated. $\mathrm{AD}=\mathrm{DFE}$-induced allergic inflammation. Data are presented as the mean \pm SE $(\mathrm{n}=$ 5). ${ }^{*} \mathrm{p}<0.05$, significantly lower than AD.
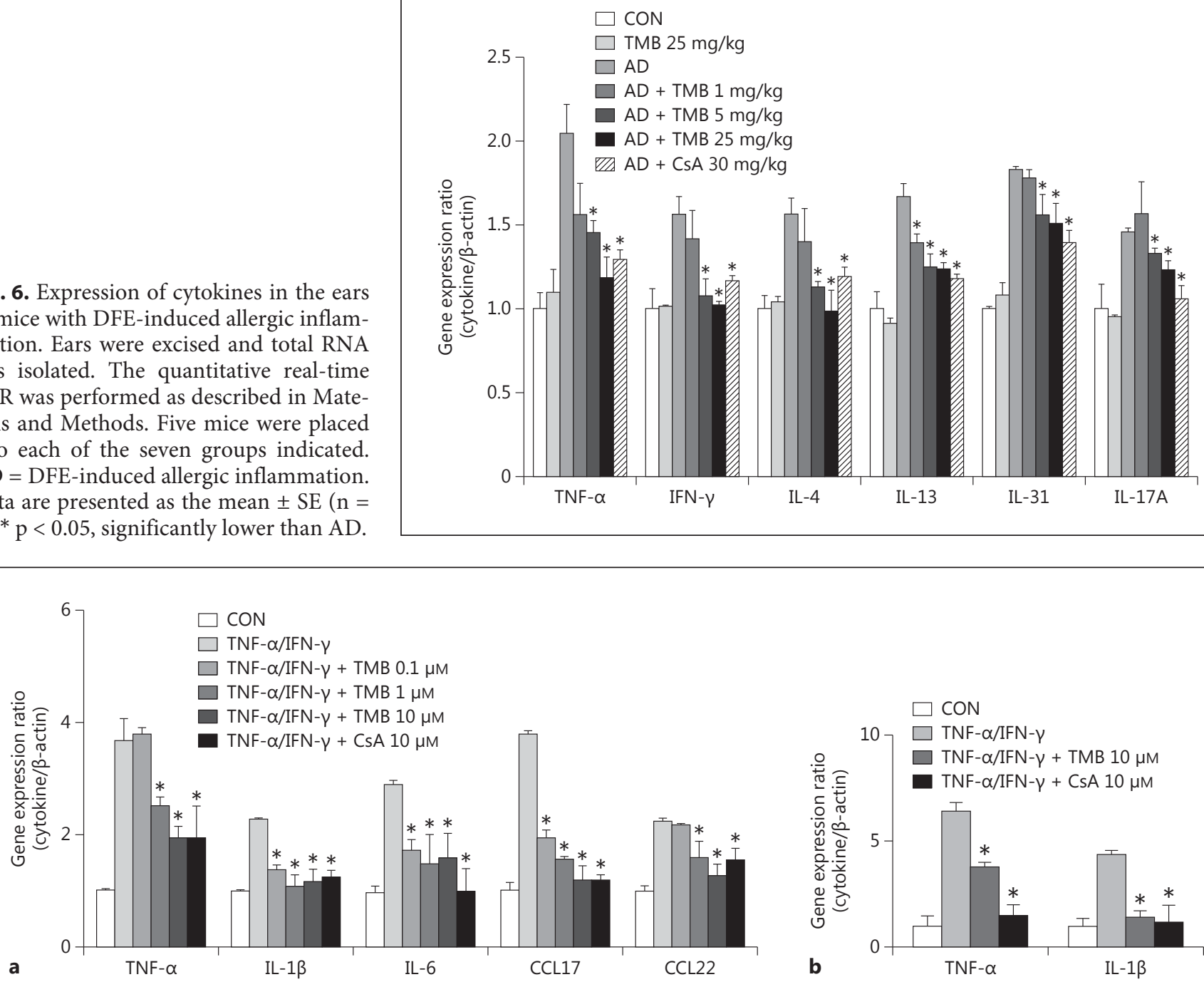

Fig. 7. Expression of cytokines and chemokines in TNF- $\alpha / \mathrm{IFN}-\gamma$ stimulated keratinocytes. a HaCaT cells were pretreated with TMB $(0.1,1.0$ or $10 \mu \mathrm{M})$ or CsA $(10 \mu \mathrm{M}) 1 \mathrm{~h}$ before stimulation with TNF- $\alpha(10 \mathrm{ng} / \mathrm{ml})$ and IFN- $\gamma(10 \mathrm{ng} / \mathrm{ml})$ for $6 \mathrm{~h}$. b 3PC cells were pretreated with TMB $(10 \mu \mathrm{M})$ or CsA $(10 \mu \mathrm{M}) 1 \mathrm{~h}$ before stimula- tion with TNF- $\alpha(10 \mathrm{ng} / \mathrm{ml})$ and IFN- $\gamma(10 \mathrm{ng} / \mathrm{ml})$ for $24 \mathrm{~h}$. Expression levels of cytokines were determined by quantitative real-time PCR. Data are presented as the mean \pm SE $(n=5) .{ }^{*} \mathrm{p}<0.05$, significantly lower than the TNF- $\alpha /$ IFN- $\gamma$-stimulated group.

\section{Discussion}

Several studies reported that natural compounds occupy a place of choice in the current pharmacopoeia [1]. Recently, many natural extracts have been introduced for the potential therapeutic agents for treating skin inflammatory disorders such as $\mathrm{AD}[15,30]$. A. xanthioides is a medicinal herb which has various medicinal effects, such as antimicrobial, antioxidative, anticancer and anti-in- flammation properties [31]. Previously, we reported the inhibitory effect of methanol extracts of $A$. xanthioides in mast cell-mediated allergic inflammations [13]. To clarifying the role of $A$. xanthioides, we isolated TMB from $A$. xanthioides by the activity-guided fractionation. In our previous study, the novel compound TMB isolated from A. xanthioides was shown to have antiallergic inflammatory effects in mast cells and animal models [16]. Based on the known antiallergic and anti-inflammatory effects
42

Int Arch Allergy Immunol 2016;170:35-45 DOI: $10.1159 / 000446510$
Jin/Choi/Choi/Kim/Baek/Lee/Jang/Lee/ Lee/Kim/Lee/Park/Lee/Park/Kim 


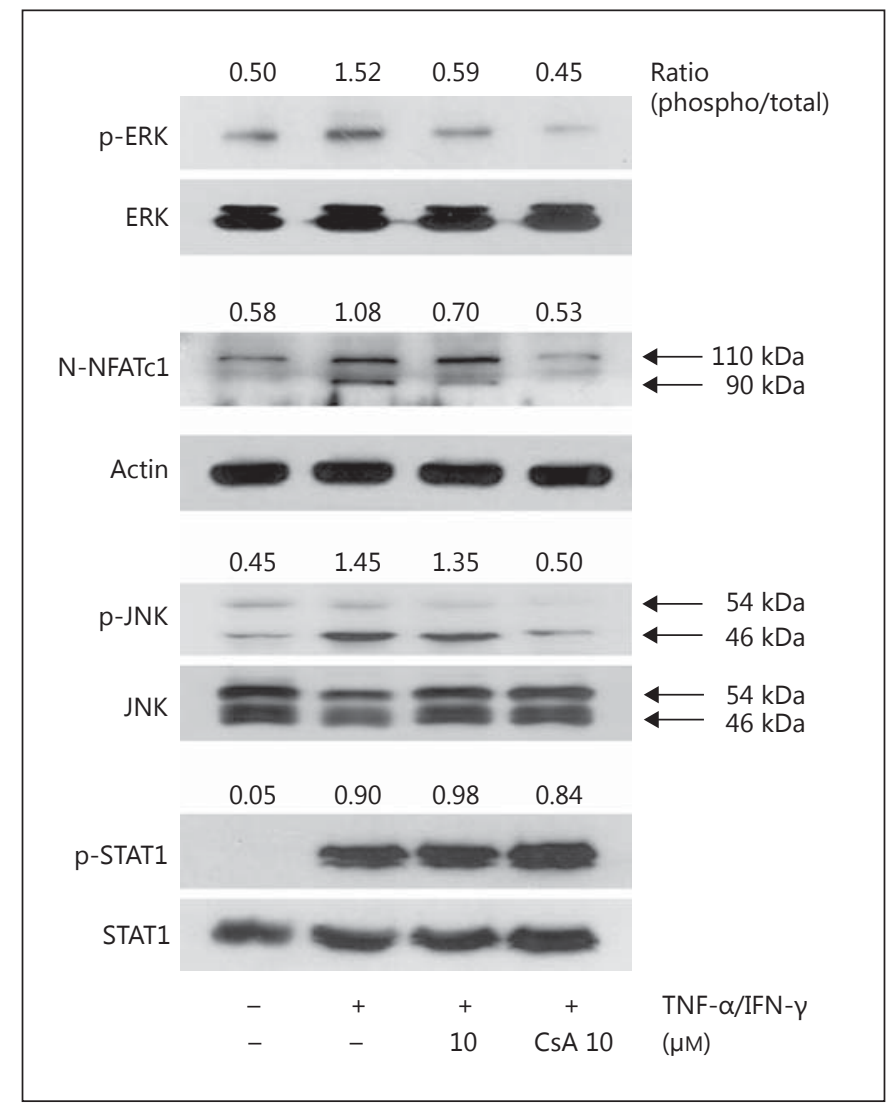

Fig. 8. Activation of MAPKs, STAT1 and NFATc1 in TNF- $\alpha /$ IFN$\gamma$-stimulated $\mathrm{HaCaT}$ cells. Cells were pretreated with TMB $(10 \mu \mathrm{M})$ or CsA $(10 \mu \mathrm{M}) 1 \mathrm{~h}$ before stimulation with TNF- $\alpha(10 \mathrm{ng} / \mathrm{ml})$ and IFN- $\gamma(10 \mathrm{ng} / \mathrm{ml})$ for $30 \mathrm{~min}$. The activation of MAPKs, NFATc1 and STAT1 was analyzed by Western blot. The data shown represent three independent experiments. The ratios of bands were measured using ImageJ software. Actin was used as a loading control. N-NFATc1 = Nucleus NFATc1.

of TMB, we demonstrated the effect of TMB on AD using in vivo and in vitro models.

DFE is known to contribute to the development of $\mathrm{AD}$ via the activation of inflammasomes in the epidermal keratinocytes $[1,32]$. Previous research showed that repeated application of DFE produced AD symptoms, including epidermis thickening, fibrosis in the dermis and the infiltration of inflammatory cells (eosinophils and mast cells) [33]. Mast cell-derived histamine and inflammatory mediators contribute to itching and inflammation in patients with $\mathrm{AD}$, and they secrete multiple mediators affecting eosinophils [10]. In addition, histamine could be a significant mediator in $\mathrm{AD}$ patients; infiltration of eosinophils in the skin of $\mathrm{AD}$ patients also aggravated the inflammatory response $[10,34]$. In our results, oral ad- ministration of TMB diminished the symptoms of $\mathrm{AD}$, such as ear thickness, dermal and epidermal thickness, eosinophils and mast cell infiltration, and serum histamine levels. Oral administration of CsA is widely used in patients with severe AD [5]. Previous research has shown that CsA is important in the pathogenesis of itch in $\mathrm{AD}$ [35]. In the DFE-induced allergic inflammation model, oral administration of TMB at high doses $(25 \mathrm{mg} / \mathrm{kg})$ had a similar anti-inflammatory effect as CsA $(30 \mathrm{mg} / \mathrm{kg})$. These results imply that TMB relieves itching and inflammatory responses in $\mathrm{AD}$ through a reduction of the inflammatory cells.

Both Th1 and Th2 cytokines contribute to AD skin lesions, Th2 cytokines for acute AD and Th1 cytokines for chronic AD [8]. Cytokines are known to affect immunoglobulin isotype switching [8]. IL-4 and IL-13 are critical for Th2 cell differentiation, IgE production and eosinophil recruitment [36]. Total IgE levels are elevated in AD patients compared to healthy individuals [37]. IL-31 is produced by Th2 cells and acts as an itch mediator in $\mathrm{AD}$ [38]. In addition, IFN- $\gamma$ is expressed in chronic AD and drives the production of IgG2a [39]. IL-17A is highly expressed in acute $\mathrm{AD}$, which has been described as an essential factor for $\mathrm{AD}$ [9]. Conclusively, the downregulation of Th1, Th2 and Th17 cytokines is necessary to modulate AD symptoms [40]. In our DFE-induced allergic inflammation mouse model, Th1 (IFN- $\gamma$ ), Th2 (IL-4, IL13 and IL-31) and Th17 (IL-17A) cytokines were upregulated in the skin of mouse ears and the draining lymph node cells. TMB significantly diminished the expression of all the Th1, Th2 and Th17 cytokines in a dose-dependent manner. In addition, TMB markedly inhibited the serum level of total IgE, DFE-specific IgE and IgG2a. These results suggest that $\mathrm{TMB}$ controlled $\mathrm{AD}$ immune responses by the downregulation of Th1, Th2 and Th17 cytokines. Based on our results, we could assume that TMB suppresses both acute and chronic AD phases.

Keratinocytes secrete cytokines and chemokines after exposure to proinflammatory cytokines and Th2 cytokines from $\mathrm{T}$ cells [34]. Keratinocytes from AD patients produce a unique profile of cytokines and chemokines following some stimulation [41]. Several studies have reported that keratinocytes are one of the main sources of TRAC/CCL17 and MDC/CCL22, which are the key mediators for the development of AD [42-44]. Stimulation with TNF- $\alpha / \mathrm{IFN}-\gamma$ in $\mathrm{HaCaT}$ cells produces TRAC/ CCL17 and MDC/CCL22, which are known to be upregulated in AD-like skin lesions [45]. In the present study, TMB suppressed the TNF- $\alpha /$ IFN- $\gamma$-induced gene expression of TNF- $\alpha$, IL-1 $\beta$, IL-6, TRAC/CCL17 and MDC/ 
CCL22 in HaCaT cells. In addition, TMB also suppressed the TNF- $\alpha /$ IFN- $\gamma$-induced gene expression of TNF- $\alpha$ and IL-1 $\beta$ in 3 PC cells. These results complement the inhibitory effect of TMB in DFE-induced allergic inflammation.

CsA is a potent immunosuppressant and often prescribed for AD [46]. CsA is known to inhibit the NFATmediated signaling pathway [46]. NFAT, a transcription factor, plays an important role in the immune system through regulation of the expression of proinflammatory cytokines [29, 47]. The MAPK pathways also play an important role in inflammatory diseases and lead to the systemic inflammatory response syndrome [48]. In particular, ERK enhances the phosphorylation of NFAT [49]. In our results, TMB markedly inhibited the activation of TNF- $\alpha$ /IFN- $\gamma$-stimulated ERK and NFATc1 in HaCaT cells. We assume that TMB inhibited the TNF- $\alpha / \mathrm{IFN}-\gamma$ stimulated expression of proinflammatory cytokines and chemokines by the blocking of ERK and NFATc1 in keratinocytes. However, further studies are needed in order to understand the exact mechanisms of TMB.
In the present report, we demonstrated that oral administration of TMB suppressed the development of AD symptoms in in vivo and in vitro models. TMB suppressed $\mathrm{AD}$ symptoms in a dose-dependent manner in the DFE-induced allergic inflammation models. TMB also inhibited the proinflammatory cytokines and chemokines through a reduction of ERK and NFATcl in keratinocytes. Furthermore, the inhibitory effect of TMB on $\mathrm{AD}$ was comparable to that of CsA. We have provided conclusive evidence that TMB could be a potential therapeutic candidate for $\mathrm{AD}$.

\section{Acknowledgements}

This work was supported by the National Research Foundation of Korea Grant funded by the Korean Government (2014R1A5A2009242, 2013R1A1A4A01006557, 2013R1A1A3009525 and 2012M3A9B6055416), and by the High Value-Added Food Technology Development Program, Ministry of Agriculture, Food and Rural Affairs.

\section{References}

1 Dai X, Sayama K, Tohyama M, Shirakata Y, Hanakawa Y, Tokumaru S, Yang L, Hirakawa S, Hashimoto K: Mite allergen is a danger signal for the skin via activation of inflammasome in keratinocytes. J Allergy Clin Immunol 2011;127:806-814.e4.

2 Choi JK, Oh HM, Lee S, Kwon TK, Shin TY, Rho MC, Kim SH: Salvia plebeia suppresses atopic dermatitis-like skin lesions. Am J Chin Med 2014;42:967-985.

3 Gittler JK, Shemer A, Suarez-Farinas M, Fuentes-Duculan J, Gulewicz KJ, Wang CQ, Mitsui H, Cardinale I, de Guzman Strong C, Krueger JG, Guttman-Yassky E: Progressive activation of $\mathrm{T}_{\mathrm{H}} 2 / \mathrm{T}_{\mathrm{H}} 22$ cytokines and selective epidermal proteins characterizes acute and chronic atopic dermatitis. J Allergy Clin Immunol 2012;130:1344-1354.

4 Bieber T: Atopic dermatitis. Ann Dermatol 2010;22:125-137.

5 Khattri S, Shemer A, Rozenblit M, Dhingra N, Czarnowicki T, Finney R, Gilleaudeau P, Sullivan-Whalen M, Zheng X, Xu H, Cardinale I, de Guzman Strong C, Gonzalez J, Suarez-Farinas M, Krueger JG, Guttman-Yassky E: Cyclosporine in patients with atopic dermatitis modulates activated inflammatory pathways and reverses epidermal pathology. J Allergy Clin Immunol 2014;133:1626-1634.

6 Koga C, Kabashima K, Shiraishi N, Kobayashi M, Tokura Y: Possible pathogenic role of Th17 cells for atopic dermatitis. J Invest Dermatol 2008;128:2625-2630.
7 Suarez-Farinas M, Dhingra N, Gittler J, Shemer A, Cardinale I, de Guzman Strong C, Krueger JG, Guttman-Yassky E: Intrinsic atopic dermatitis shows similar Th2 and higher Th17 immune activation compared with extrinsic atopic dermatitis. J Allergy Clin Immunol 2013;132:361-370.

8 Spergel JM, Mizoguchi E, Oettgen H, Bhan AK, Geha RS: Roles of Th1 and Th2 cytokines in a murine model of allergic dermatitis. J Clin Invest 1999;103:1103-1111.

9 Auriemma M, Vianale G, Amerio P, Reale M: Cytokines and $\mathrm{T}$ cells in atopic dermatitis. Eur Cytokine Netw 2013;24:37-44.

10 Guttman-Yassky E, Nograles KE, Krueger JG: Contrasting pathogenesis of atopic dermatitis and psoriasis - part ii: immune cell subsets and therapeutic concepts. J Allergy Clin Immunol 2011;127:1420-1432.

11 Albanesi C, Scarponi C, Giustizieri ML, Girolomoni G: Keratinocytes in inflammatory skin diseases. Curr Drug Targets Inflamm Allergy 2005;4:329-334.

12 Trautmann A, Akdis M, Schmid-Grendelmeier P, Disch R, Brocker EB, Blaser K, Akdis CA: Targeting keratinocyte apoptosis in the treatment of atopic dermatitis and allergic contact dermatitis. J Allergy Clin Immunol 2001;108:839-846.
13 Kim SH, Shin TY: Amomum xanthiodes inhibits mast cell-mediated allergic reactions through the inhibition of histamine release and inflammatory cytokine production. Exp Biol Med (Maywood) 2005;230:681-687.

14 Guo DJ, Cheng HL, Chan SW, Yu PH: Antioxidative activities and the total phenolic contents of tonic Chinese medicinal herbs. Inflammopharmacology 2008;16:201-207.

15 Han NR, Kim HM, Jeong HJ: The $\beta$-sitosterol attenuates atopic dermatitis-like skin lesions through down-regulation of TSLP. Exp Biol Med (Maywood) 2014;239:454-464.

16 Je IG, Choi HG, Kim HH, Lee S, Choi JK, Kim SW, Kim DS, Kwon TK, Shin TY, Park PH, Khang D, Kim SH: Inhibitory effect of 1,2,4,5-tetramethoxybenzene on mast cellmediated allergic inflammation through suppression of IкB kinase complex. Toxicol Appl Pharmacol 2015;287:119-127.

17 Choi JK, Oh HM, Lee S, Park JW, Khang D, Lee SW, Lee WS, Rho MC, Kim SH: Oleanolic acid acetate inhibits atopic dermatitis and allergic contact dermatitis in a murine model. Toxicol Appl Pharmacol 2013;269:72-80.

18 Kwon HK, Lee CG, So JS, Chae CS, Hwang JS, Sahoo A, Nam JH, Rhee JH, Hwang KC, Im $\mathrm{SH}$ : Generation of regulatory dendritic cells and CD4+Foxp3+ $\mathrm{T}$ cells by probiotics administration suppresses immune disorders. Proc Natl Acad Sci USA 2010;107:2159-2164. 
19 Choi JK, Kim SH: Inhibitory effect of galangin on atopic dermatitis-like skin lesions. Food Chem Toxicol 2014;68:135-141.

20 Bae Y, Lee S, Kim SH: Chrysin suppresses mast cell-mediated allergic inflammation: involvement of calcium, caspase- 1 and nuclear factor-кB. Toxicol Appl Pharmacol 2011;254: 56-64.

21 Lee S, Yun HS, Kim SH: The comparative effects of mesoporous silica nanoparticles and colloidal silica on inflammation and apoptosis. Biomaterials 2011;32:9434-9443.

22 Zhang B, Alysandratos KD, Angelidou A, Asadi S, Sismanopoulos N, Delivanis DA, Weng Z, Miniati A, Vasiadi M, Katsarou-Katsari A, Miao B, Leeman SE, Kalogeromitros D, Theoharides TC: Human mast cell degranulation and preformed TNF secretion require mitochondrial translocation to exocytosis sites: relevance to atopic dermatitis. J Allergy Clin Immunol 2011;127:1522-1531.e8.

23 Kawakami T, Ando T, Kimura M, Wilson BS, Kawakami Y: Mast cells in atopic dermatitis. Curr Opin Immunol 2009;21:666-678.

24 Homey B, Steinhoff M, Ruzicka T, Leung DY: Cytokines and chemokines orchestrate atopic skin inflammation. J Allergy Clin Immunol 2006;118:178-189.

25 Guttman-Yassky E, Nograles KE, Krueger JG: Contrasting pathogenesis of atopic dermatitis and psoriasis - part I: clinical and pathologic concepts. J Allergy Clin Immunol 2011;127: 1110-1118.

26 Kim OK, Chang JY, Nam DE, Park YK, Jun W, Lee J: Effect of Canavalia gladiata extract fermented with Aspergillus oryzae on the development of atopic dermatitis in $\mathrm{NC} / \mathrm{Nga}$ mice. Int Arch Allergy Immunol 2015;168: 79-89.

27 Kim SY, Sohn EJ, Kim DW, Jeong HJ, Kim MJ, Kang HW, Shin MJ, Ahn EH, Kwon SW, Kim YN, Kwon HJ, Kim TY, Lee KS, Park J, Eum WS, Choi SY: Transduced PEP-1-FK506BP ameliorates atopic dermatitis in NC/ Nga mice. J Invest Dermatol 2011;131:14771485.

28 Park JH, Kim MS, Jeong GS, Yoon J: Xanthii fructus extract inhibits TNF- $\alpha / \mathrm{IFN}-\gamma$ induced Th2-chemokines production via blockade of NF- $\kappa$ B, STAT1 and p38-MAPK activation in human epidermal keratinocytes. J Ethnopharmacol 2015;171:85-93.
29 Pham LV, Tamayo AT, Li C, Bueso-Ramos C, Ford RJ: An epigenetic chromatin remodeling role for NFATc1 in transcriptional regulation of growth and survival genes in diffuse large B-cell lymphomas. Blood 2010;116:38993906.

30 Beghyn T, Deprez-Poulain R, Willand N, Folleas B, Deprez B: Natural compounds: leads or ideas? Bioinspired molecules for drug discovery. Chem Biol Drug Des 2008;72:3-15.

31 Yan Y, Li X, Wan M, Chen J, Li S, Cao M, Zhang D: Effect of extraction methods on property and bioactivity of water-soluble polysaccharides from Amomum villosum. Carbohydr Polym 2015;117:632-635.

32 Kimura M, Meguro T, Ito $\mathrm{Y}$, Tokunaga $\mathrm{F}$, Hashiguchi A, Seto S: Close positive correlation between the lymphocyte response to hen egg white and house dust mites in infants with atopic dermatitis. Int Arch Allergy Immunol 2015;166:161-169.

33 Gao XK, Nakamura N, Fuseda K, Tanaka H, Inagaki $\mathrm{N}$, Nagai $\mathrm{H}$ : Establishment of allergic dermatitis in NC/Nga mice as a model for severe atopic dermatitis. Biol Pharm Bull 2004; 27:1376-1381.

34 Werfel T: The role of leukocytes, keratinocytes, and allergen-specific IgE in the development of atopic dermatitis. J Invest Dermatol 2009; 129:1878-1891.

35 Wahlgren CF, Scheynius A, Hagermark O: Antipruritic effect of oral cyclosporin A in atopic dermatitis. Acta Derm Venereol 1990; 70:323-329.

36 Brandt EB, Sivaprasad U: Th2 cytokines and atopic dermatitis. J Clin Cell Immunol 2011; 2:110.

$37 \mathrm{Wu}$ LC, Scheerens $\mathrm{H}$ : Targeting IgE production in mice and humans. Curr Opin Immunol 2014;31C:8-15.

$38 \mathrm{Wu}$ LC, Scheerens H: Targeting IgE production in mice and humans. Curr Opin Immunol 2014;31:8-15.
39 Jin HL, Kumar L, Mathias C, Zurakowski D, Oettgen H, Gorelik L, Geha R: Toll-like receptor 2 is important for the $\mathrm{T}_{\mathrm{H}} 1$ response to $\mathrm{cu}$ taneous sensitization. J Allergy Clin Immunol 2009; 123:875-882.

40 Hwang JS, Kim JE, Yu YB, Im SH: Modulation of experimental atopic dermatitis by topical application of Gami-Cheongyeul-SodokEum. BMC Complement Altern Med 2013; 13:312.

41 Leung DY, Boguniewicz M, Howell MD, Nomura I, Hamid QA: New insights into atopic dermatitis. J Clin Invest 2004;113:651-657.

42 Saeki H, Tamaki K: Thymus and activation regulated chemokine (TARC)/CCL17 and skin diseases. J Dermatol Sci 2006;43:75-84.

43 Kwon DJ, Bae YS, Ju SM, Goh AR, Youn GS, Choi SY, Park J: Casuarinin suppresses TARC/CCL17 and MDC/CCL22 production via blockade of NF- $\mathrm{kB}$ and STAT1 activation in HaCaT cells. Biochem Biophys Res Commun 2012;417:1254-1259.

44 Qi XF, Kim DH, Yoon YS, Li JH, Jin D, Teng YC, Kim SK, Lee KJ: Fluvastatin inhibits expression of the chemokine MDC/CCL22 induced by interferon- $\gamma$ in HaCaT cells, a human keratinocyte cell line. Br J Pharmacol 2009;157:1441-1450.

45 Vestergaard C, Bang K, Gesser B, Yoneyama H, Matsushima K, Larsen CG: A Th2 chemokine, TARC, produced by keratinocytes may recruit CLA+CCR4+ lymphocytes into lesional atopic dermatitis skin. J Invest Dermatol 2000;115:640-646.

46 Wilson SR, Thé L, Batia LM, Beattie K, Katibah GE, McClain SP, Pellegrino M, Estandian DM, Bautista DM: The epithelial cell-derived atopic dermatitis cytokine TSLP activates neurons to induce itch. Cell 2013;155:285295.

47 Park K, Park JH, Yang WJ, Lee JJ, Song MJ, Kim HP: Transcriptional activation of the IL31 gene by NFAT and STAT6. J Leukoc Biol 2012;91:245-257.

48 Arbabi S, Maier RV: Mitogen-activated protein kinases. Crit Care Med 2002;30:S74-S79.

49 Porter CM, Havens MA, Clipstone NA: Identification of amino acid residues and protein kinases involved in the regulation of NFATc subcellular localization. J Biol Chem 2000; 275:3543-3551.
TMB Relieves Mite-Induced Allergic Inflammation
Int Arch Allergy Immunol 2016;170:35-45 DOI: $10.1159 / 000446510$ 